\title{
Geografia do cangaço: concepções conceituais para pensar o banditismo sertanejo
}

\author{
Geography of cangaço: conceptual ideas for thinking the backcountry banditry
}

\author{
Ana Paula Rodrigues Costa \\ Programa de Pós-graduação em Geografia, Universidade Estadual do Ceará, Fortaleza, \\ Ceará, Brasil \\ *E-mail para correspondência: anapaula-rodriguesdacosta@bol.com.br
}

Recebido (Received): 16/09/2020

Aceito (Accepted): 11/06/2021

Resumo: Este artigo parte de algumas proposições suscitadas ao longo da pesquisa de mestrado objetivando discorrer ideias a respeito do conceito de banditismo social elaborado por Eric Hobsbawm e a costumeira aplicação desse conceito em alguns trabalhos para caracterizar o movimento do cangaço, padronizando, dessa forma, lugares, paisagens e sujeitos sem levar em consideração as implicações ao homogeneizar movimento do cangaço como banditismo social, transferindo, assim, a teoria para conceituar diferentes movimentos sociais e culturais. Pensando nessa discussão, ponderam-se observações de cunho históricocultural para a existência de bandos de cangaceiros no sertão nordestino, pontuando as relações que permeavam a sociedade sertaneja da época, correlacionando às questões de honra, valentia e "cabra-macho", agregada à conexão de vivência no ambiente da caatinga, que constituiu uma geografia do cangaço, presente no contexto cultural do sujeito sertanejo nordestino com o meio ambiente a partir dos saberes populares que garantiam aos cangaceiros a vivência e a sobrevivência como nômades. A base cultural de vivência sertaneja nordestina, constituída por meio da relação do código moral sertanejo da não desmoralização, culminou, na visão dos sujeitos sertanejos nordestinos, o reconhecimento de uma geografia do cangaço desenvolvida pela atuação dos bandos de cangaceiros que asseguram, até hoje, narrativas, quer sejam de admiração ou de aversão aos bandidos/cangaceiros, atribuindo, sobretudo, um lugar de destaque após episódios de mortes trágicas sofridas por alguns cangaceiros.

Palavras-chave: Cangaço; Banditismo Social; Sertão Nordestino; Sujeitos.

Abstract: This article starts from some proposals raised during the master's research aiming to discuss ideas about the concept of social banditry developed by Eric Hobsbawm and the usual application of this concept in some works to characterize the movement of the cangaço, standardizing places, landscapes and subjects, without considering the implications of homogenizing the cangaço movement as social banditry, thus transferring the theory to conceptualize different social and cultural movements. Thinking about this discussion, historical-cultural observations are considered for the existence of bands of cangaceiros in the northeastern hinterland, punctuating the relationships that permeated the backcountry society of the time, correlating with the issues of honor, bravery and "cabra-macho", added to the connection of experience in the caatinga environment, which constituted a geography of cangaço, present in the cultural context of the subjects from the northeastern hinterland with the environment based on popular knowledge that guaranteed cangaceiros the experience and survival as nomads. The cultural base of northeastern hinterland living, constituted through the relation of the hinterland moral code of non-demoralization, culminated, in the view of the hinterland northeastern subjects, the recognition of a geography of cangaço developed by the performance of the bands of cangaceiros that ensure, until today, narratives, whether of admiration or aversion to bandits/cangaceiros, attributing, above all, a prominent place after episodes of tragic deaths suffered by some cangaceiros.

Keywords: Cangaço; Social Banditry; Northeastern hinterland; Subjects. 


\section{Introdução}

As condições de subserviência e a falta de melhores meios de sobrevivência, no sertão nordestino, foram à base para o surgimento de diversos movimentos populares: ora encampados isoladamente, ora de maneira coletiva, em várias localidades do Nordeste. Agravado pelas condições naturais do clima semiárido fez emergir diversos movimentos populares, dos quais se destaca o cangaço, não sendo apenas um movimento ligado a questões sociais, mas também a questões culturais que se produziram no processo de apropriação das áreas do sertão nordestino.

O movimento do cangaço é caracterizado pela figura de homens valentes, destemidos, frutos de uma cultura sertaneja, no qual foi alicerçado a ideia de "cabra macho", que por sua vez, corrobora com o código moral da honra sertaneja. Essa relação está diretamente ligada à cultura de "homens de bem", que muitas vezes, aderiam ao movimento do cangaço, por motivos de vingança.

A vingança estava relacionada a muitas questões, mas, sobretudo, a assédios de cunho moral. A desmoralização sofrida por um sertanejo nordestino, significava estar banido da classe de "homens de bem", e denotava a desonra familiar. Para tanto, o cangaço se configurava como meio de reaver a honra, e era um direito legitimo do sujeito que fora desmoralizado.

Desse modo, o movimento do cangaço se caracterizou como uma ação de levante social em que, muitas vezes, os cangaceiros agiam de modo "inconsciente", sem um entendimento político do seu papel de atores sociais, mesmo quando desafiavam a estrutura política, social e econômica da época.

A organização social no Nordeste fazia com que as famílias ficassem reféns de alguma ordem, quer seja dos coronéis, quer seja da igreja. O mandonismo, notadamente no Nordeste, fez com que, ao longo dos séculos, surgissem movimentos que sempre estavam ligados a um líder. As lideranças comandavam o povo nordestino que, no geral, o aprisionava sob suas ordens ou preceitos. Era comum que as famílias estivessem reunidas sob a "proteção" de coronéis ou líderes religiosos como forma de assegurar-lhes a sobrevivência.

O movimento do cangaço teve maior expressão na passagem do século XIX para o XX, intensificando a formação de bandos armados. Pericás (2010) caracterizou o cangaço como endêmico e epidêmico; para o autor, antes de 1890, o cangaço se configurava como endêmico, pois a aparição de bandos armados se dava de forma esporádica e muitos deles estavam subjugados às ordens de um determinado coronel. Já nas primeiras décadas do século XX, o cangaço chegou ao auge de sua existência como cangaço epidêmico, porque foi entre as décadas de 1890 a 1940 que mais surgiram bandos independentes pelo sertão nordestino, representados por lideranças como Antônio Silvino, Sinhô Pereira e Lampião, considerados como alguns dos maiores nomes no cangaço.

As histórias de atuação dos bandos de cangaceiros, são narradas em diversos trabalhos, quer seja, de cunho cientifico ou literário. Em algumas pesquisas, o movimento do cangaço, é conceituado como banditismo social, a partir do historiador, Eric Hobsbawm, para caracterizar a ação de sujeitos que decidiam viver como nômades, ditando suas próprias regras, e que a sociedade via esses homens como heróis, justiceiros, líderes de sua libertação.

Conceituar o movimento do cangaço na teoria de banditismo social denota algumas implicações. Uma delas é o fato de aplicar uma teoria conceitual para agrupar movimentos em qualquer parte do globo terrestre, sem levar em consideração, as especificidades de cada localidade e da cultura em que fora constituídos cada sujeito, nas mais vastas áreas de cada continente.

Desse modo, objetiva-se com esse trabalho apresentar algumas considerações a respeito dos conceitos de banditismo social, e movimento cangaço, para demonstrar algumas lacunas existentes entre os conceitos, sobretudo, das particularidades da atuação dos sujeitos cangaceiros, na cultura sertaneja nordestina.

\section{Algumas considerações a respeito dos conceitos de banditismo social e movimento do cangaço}

De acordo com Hobsbawm (2015, p. 22-23), do ponto de vista social, a história do banditismo se divide em três etapas: "[...] seu nascimento, quando as sociedades anteriores ao bandido passam a fazer parte de sociedades com classes e Estado; sua transformação a partir da ascensão do capitalismo, local e mundial; e sua longa trajetória sob Estados e regimes sociais intermediários".

Hobsbawm contextualiza o banditismo e o classifica como homogêneo para traçar o perfil de bandidos de diversos países, em diferentes continentes do globo. Na obra, Rebeldes primitivos, o autor traça o seguinte argumento: "Descrever o bandido 'ideal' não é, de modo algum, faltar à realidade. A característica mais surpreendente do banditismo social é sua notável uniformidade e padronização" (HOBSBAWM, 1978, p. 23). No entanto, essa afirmativa nos parece generalizar países, regiões, sujeitos, movimentos, etc., para 
conceituar a ideia de banditismo social, deixando de considerar as especificidades dos sujeitos e as relações socioculturais produzidas em determinado espaço.

A história do banditismo social, assim como a história de outros movimentos, não deve ser homogeneizada com o intuito de conceituá-los, pois se distinguem em sua forma de atuação, de ideias e de sujeitos. Dessa maneira, não é possível aplicar um conceito para caracterizar um movimento como homogêneo para distintos locais. Conceituar, por exemplo, o movimento do cangaço como banditismo social a partir da atuação de grupos de bandidos que atuaram no sul da Itália ou em regiões do continente africano não nos parece uma ideia acertada.

Na obra, Bandidos, Hobsbawm faz referência ao movimento do cangaço a partir da figura de Lampião, caracterizando-o na categoria de vingador. No entanto, o autor afirma que a imagem lhe interessa mais do que a realidade, expressando, desse modo, o que era retratado nas lendas e no folclore popular contidos em canções, romances e livretos de cordéis. O que demonstra que não houve, por parte do autor, um aprofundamento de base documental para categorizar o movimento do cangaço na categoria de banditismo social. De acordo com Lins (1998, p. 170), Hobsbawm "[...] deixa de lado os documentos das polícias ou do judiciário, quer dizer os arquivos do poder".

Para Pericás (2010), a fundamentação utilizada por Hobsbawm para categorizar o movimento do cangaço como banditismo social é questionável pelo fato do autor ter empregado modelos universalizantes para apontar traços comuns em determinados tipos de bandidos do meio rural de diversos países, categorizando-os num mesmo esquema teórico com pouca ou nenhuma base documental para comprovar sua hipótese.

Ainda sobre a ideia de banditismo social de Hobsbawm, Pericás (2010) acrescenta que discutir o movimento do cangaço utilizando a figura de Lampião como exemplo para contrapor outros bandidos de países distintos não configura exemplificação dessa categoria. $\mathrm{O}$ autor escreve que mais apropriado para abordar tal ideia seria utilizar o exemplo do cangaceiro Jesuino Brilhante. As obras escritas a respeito deste cangaceiro, quer sejam científicas ou não, o tratam como um bandido nobre, associado em alguns escritos à figura do Hobin Hood, sendo no imaginário das famílias do meio rural um herói de sua libertação, o justiceiro que lhes traria uma nova vida.

Para Hobsbawm, os "bandidos sociais" compartilhavam dos mesmos valores morais das famílias camponesas que esperavam sua libertação, a partir desses bandidos que proclamariam a liberdade para as famílias que viviam a margem da sociedade. A proposição de banditismo de Hobsbawm não é possível de entender e de explicar os grupos de "bandidos" como os cangaceiros. O autor reduz a análise do fenômeno às relações de classes, à riqueza e ao poder nas sociedades camponesas, sobretudo na segunda fase de sua história.

No entanto, a condição de sertanejo nordestino impunha aos cangaceiros uma lógica que não se encontrava diretamente relacionada à noção de classe, mas às condições de sujeitos sertanejos nordestinos, intermediados pelas relações culturais, constituídas socialmente em um espaço próprio, um espaço vivido, a saber: a caatinga, na qual se sobressaia a questão da honra que levou vários homens a ingressarem no movimento do cangaço por sua condição cultural de sujeito enquanto "cabra macho". As relações culturais, intermediadas em uma dinâmica espacial, constituíram esses sujeitos e um contexto histórico-geográfico.

No processo de apropriação colonial destaca-se duas áreas economicamente distintas, as áreas de litoral, principalmente a Zona da Mata, voltada para a produção da Monocultura escravagista da cana-de-açúcar, ligando esse território a contexto da metrópole, logo, alguns equipamentos de produção e controle da lógica capitalista se destacavam no espaço social, enquanto que as áreas de sertões, sendo este o território da pecuária (atividade de suporte econômico), destacava-se por um vasto território, no qual os equipamentos de controle da lógica capitalistas encontravam-se dispersos. "No período colonial, assim como no momento da Independência, a grande extensão de terra, correspondendo ao interior do país, permanecia alheia aos acontecimentos litorâneos, desintegrada da efervescência dos núcleos urbanos, das atividades econômicas e sociais do litoral." (ALMEIDA, 2003, p. 74)

Exatamente esse contexto de distanciamento físico, mas também de relações, fez com que o sertão nordestino tornasse um lugar com expressões diferentes do litoral. A cultura do interior do sertão não se relacionava com a do litoral. Os sujeitos que estabeleceram moradias no interior, estavam embasados numa cultura de valentia, da vivência com o ambiente, da experiência com o espaço, da relação intima com o lugar.

Outro fator que cabe destaque são os processos de disputadas instaurados pela resistência indígena e dos escravos libertos, ao longo desse vasto território, marcado pela caatinga ressequida. Dentre os vários processos de luta por território que podem ser destacados, cabe citar a confederação dos Kariris e a de Palmares, destacando o contexto sociocultural que marca esse território e produz marcas culturais presentes 
nos sujeitos. Essas marcas culturais estão relacionadas ao contexto histórico-geográfico de vivência dos sujeitos em seus territórios, sobretudo pelo processo de resistência que os sertanejos nordestinos vivenciaram ao longo da história.

"A construção discursiva sobre o sertão espelha a maneira como ele é pensado e uma maneira específica de 'ver' o mundo." (ALMEIDA, 2003, p. 71). O sertão tem múltiplos olhares, múltiplas interpretações. Culturalmente o sujeito sertanejo nordestino foi vivenciando uma ideia de sertão que revestiu esse sujeito de olhares, de resistências, afetividades, etc., que o torna um indivíduo conhecedor da caatinga.

O sujeito cangaceiro, culturalmente constituído no sertão nordestino, dotado dessas vivências sertanejas, sobretudo pela questão da valentia, da honradez, era característico pela não aceitação da desonra. Característica essa, que ressignificou ao longo do tempo a ideia de "cabra macho" reafirmando dessa forma, a imagem de homens corajosos, destemidos, ou propícios a violência, que desafiavam a todos em nome da honra. De acordo com Gustavo Barroso (2012, p. 29) "no sertão quem não se vinga está moralmente morto." Essa máxima fora o motivo maior para muitos sujeitos aderirem ao movimento do cangaço. Nessa seara, a imagem de "cabra macho" até hoje é utilizada para justificar a aderência ao movimento do cangaço e associar as ações cangaceiras como ato de coragem e valentia em nome da honra.

O sentido de honradez, de provar que era "cabra macho", homem de bem, era tão forte que qualquer situação que afetasse a honra era motivo para revoltar-se e agir contra quem praticava atos opressores. Essas ações de valentia, de lutar e morrer pela honra, eram o principal discurso entre os cangaceiros, configurandose como a principal razão para a aderência e atuação no movimento do cangaço.

Nessa seara, a ideia de banditismo social desenvolvida por Hobsbawm não apresenta elementos necessários para se pensar o movimento do cangaço. As bases para constituir as fontes de informações do autor, deram-se por informações ficcionais de romances e folhetos de cordéis: "Ao traçar o retrato canônico do bandido social, Hobsbawm não questiona, de maneira sistemática, a natureza dos dados que analisa" (LINS, 1998, p. 170). Embora os cordéis e romances tratassem da realidade, não trazia a verdade dos fatos por completo e havia muito mais uma história romantizada e heroica que o povo gostava de ouvir como distração, principalmente em ambientes de vivência coletiva como, por exemplo, as feiras.

Barros (2018) publicou o artigo Cangaço - violência no Sertão do Nordeste na revista Ponta de Lança, em 2018, em comemoração aos 80 anos da morte de Lampião, realizando uma reflexão a respeito da violência no período de atuação de Lampião e correlacionando com a violência empreendida atualmente. Pondera que muitas das pesquisas exercem certa influência na disseminação de ideias em relação a "rebeldias", na perspectiva de autores europeus e norte-americanos, sem uma preocupação crítica em submeter essas teorias à análise da realidade brasileira.

A autora argumenta que se deve ter cautela ao utilizar a teoria de banditismo social de Hobsbawm para categorizar o movimento do cangaço, pois a realidade em que o autor desenvolveu a teoria não condiz com a realidade de tantos movimentos sobre os quais discorre em seus trabalhos, "[...] Cangaceiro é bandido social, e catolicismo popular é fanatismo e messianismo. É como se tivesse caído uma maldição sobre o Brasil contemporâneo, impedindo que os brasileiros criassem teorias sobre seu povo" (BARROS, 2018, p. 74).

Nesse sentido, pontuar o movimento do cangaço como banditismo social na concepção de Hobsbawm, a nosso ver, nem explica o movimento, nem o caracteriza como banditismo social. Pelas características locais e o contexto sociocultural dos sujeitos envolvidos no movimento, apontamos para a ideia de banditismo sertanejo, que traça o perfil do movimento a partir da "característica" do sertanejo nordestino.

Paiva (2004, p. 7) discorre que o cangaço representou a evolução das atividades dos jagunços que deixaram a obediência aos coronéis e passaram a agir de forma independente, "[...] formando bandos sob rigorosa chefia, muitas vezes a serviço dos fazendeiros e políticos, que lhes compravam proteção ou encomendava missões a executar".

Destarte, o cangaceiro não dependia diretamente do coronel para sua sobrevivência, uma vez que, diferentemente do jagunço, do capanga, do guarda-costas e de outras figuras que antecederam o cangaceiro, este último não era um trabalhador à serviço unicamente do coronel, mas, quando contratado, protegia e era protegido; por outro lado, não devia obediência e fidelidade ao coronel como empregado e patrão, posto que o cangaceiro tinha autonomia de controlar e manter seu próprio bando.

Barros (2007), analisando a relação entre coronéis e chefes políticos, na figura de protetores e coiteiros de cangaceiros, apresenta uma reportagem do jornal Tempo de Contar, realizada pelo jornalista Joel Silveira, em 1944, na qual o jornalista entrevistou alguns cangaceiros do bando de Lampião na penitenciária de Salvador e o ex-cangaceiro Cacheado relatou que, no período do cangaço, se matava muito, mas a culpa não era restrita aos cangaceiros. Muito mais culpa tinham os "homens educados" que os auxiliavam com 
munição e outras proteções e que, se bandidos eram os cangaceiros, os homens de bem não deveriam tê-los ajudado.

A proposição de banditismo sertanejo vincula-se às relações socioespaciais constituídas pelos sujeitos a partir da vivência coletiva em um dado espaço e em uma dada realidade histórica, o que acabou por produzir as bases nas quais se desenvolveu o movimento do cangaço, ou seja, consideramos um espaço em que se reproduziram as relações culturais e sociais, o sertão da caatinga, juntamente à subjetividade dos sujeitos que ressignificaram a forma de vida, cominando em diferentes movimentos nesse ambiente, dentre eles, o cangaceirismo, uma forma de banditismo sertanejo que possui relações próprias estabelecidas em um tempo e espaço próprio.

Os sujeitos pertencentes ao movimento do cangaço e a forma como passaram a atuar no cangaço relacionam-se diretamente ao contexto cultural e espacial de uma localidade específica. Sobre este aspecto, podemos dialogar com a ideia de Berdoulay et. al. (2012, p. 108) que entendem: "[...] O sujeito e o lugar funcionam como duas noções primordiais da experiência humana. [...] O sujeito e o lugar são, cada um, constitutivos do outro".

Nessa senda, o sujeito produz o lugar pelos seus sentidos e afetividade, ao passo que, ao produzir o lugar, é transformado por este. A constituição de um lugar amplo como o sertão nordestino liga-se à vivência de um grupo social que se reconhece em uma narrativa comum, produz seus costumes, modos de vida e concepções culturais, tais como a ideia de "cabra macho" e de honra. Nesse sentido, é fundamental entender os aspectos culturais, vinculados a um determinado grupo de sujeitos, bem como a forma de espacializar tais aspectos dada a base material que se apresenta, ou seja, o espaço tomado como ambiente no qual se desenvolvem as relações socioculturais. Tais relações constituem os sertanejos nordestinos e sem a vivência que liga o sujeito a um lugar não será possível compreender a dinâmica da vivência e da atuação que cercam os bandos de cangaceiros.

É nesse sentido que corroboramos com a ideia apresentada por Barros (2018), ao defender a estruturação de conceitos e categorias que permitam entender a realidade local. Percebe-se uma possibilidade de diálogo entre os argumentos apresentados por Barros (2018) e as proposições de Berdoulay et. al (2012), ao discutir a importância da interpretação de um fenômeno a partir de suas especificidades locais ao invés de estabelecer comparativos com a realidade mais global, pois os fenômenos apresentam diferenças entre sujeitos e sua relação com o espaço.

Esta relação a qual se pretende parte do entendimento do sujeito, do fenômeno do qual participa e sua relação com o espaço vivido onde o fenômeno é produzido. Tais relações que levaram vários sujeitos nordestinos a ingressarem no cangaço vincula-se ao período de apropriação territorial do sertão nordestino que foi marcado por uma política de expansão colonialista, seguindo a lógica do capitalismo mercantil da época. A área valorizada, do ponto de vista financeiro para metrópole, fora a Zona da Mata, na qual se desenvolvia a monocultura escravista da cana-de-açúcar. O sertão da caatinga teve sua ocupação voltada a uma base econômica de suporte, a pecuária, cultura esta voltada, principalmente, para a produção do gado, pensando no abastecimento da área de produção da cana-de-açúcar com animais de tração, carne, couro e outros.

O sentido de valentia, de "cabra-macho" está voltado à forma de apropriação dessas áreas. Os homens destemidos foram escolhidos para ocupar os espaços mais longínquos da colônia. Este aspecto se reverbera e passa a fazer parte do cotidiano e da cultura local como um aspecto que os marca.

Além de uma atividade econômica secundária, o clima semiárido do sertão da caatinga contribuiu para uma condição econômica desfavorecida, onde poucos possuíam muito e muitos não possuíam nada. A produção do ambiente local, transformado em lugar pela afetividade dos sujeitos, compreende o universo de significados dos sertanejos nordestinos, bem como dos sujeitos que passaram a ingressar no movimento do cangaço. O espaço, assim, configura-se e apresenta-se como base de compreensão para o fenômeno do cangaço, tomado como banditismo sertanejo.

Ao apresentar as ideias de Berdoulay et. al, pensando em relacioná-las com a visão defendida por Barros, entende-se que os primeiros realizaram suas exposições pensando como a ciência tem refletido a relação espaço-lugar-sujeito e argumentando que o sujeito teria ficado sempre em segundo plano. Ao pensar questões relacionadas à defesa do sentido de pertencimento e identidade, esta apontaria para um reconhecimento de tais sujeitos em defesa de seus laços culturais e seu vínculo com o lugar.

Desse modo, o sujeito deve ser considerado como elemento para a compreensão de determinados contextos, evitando-se realizar uma análise na qual os sujeitos são relativizados para se encaixarem em tramas determinadas por circunstâncias exteriores. Os sujeitos produzem sua própria identidade, a 
consciência de si mesmo, em interação com o contexto de suas ações que moldam o lugar em um determinado tempo-espaço.

"Uma sociologia do sujeito e uma "geografia moral" centrada na questão do lugar chegam, assim, a convergências que podem fornecer os fundamentos de um discurso refletido sobre a natureza do bem na sociedade" (BERDOULAY et. al, 2012, p. 100-101).

Tomando por base as questões levantadas e refletidas pelos autores, pensa-se a possibilidade de, partindo do contexto do movimento do cangaço, basear a discussão desse fenômeno no banditismo sertanejo, sendo uma possibilidade de compreensão da formação e da atuação dos bandos de cangaceiros, dialogando a perspectiva cultural do sujeito em sua relação direta com o lugar, dados os elementos apresentados ao longo do texto.

O que nos é interessante da obra de Hobsbawm (2015) é o sentido da origem da palavra bandido: partindo do seu significado que provém do italiano bandito, qual seja, homem banido, posto fora da lei.

Pensar o contexto do cangaço como instrumento de reaver a honra, nos leva a pensar que alguns homens foram expostos a uma vergonha, humilhação, na qual se sentiam banidos dos círculos de moralidade em que viviam os "homens de bem" da sociedade sertaneja nordestina, passando a serem enquadrados como homens baderneiros.

\section{Geografia do cangaço: atuação de bandos de cangaceiros no sertão nordestino}

Nessa seara, é preciso entender o termo cangaço e suas derivações. Conforme Luiz Pericás explica, (2010, p. 13-14) o vocábulo é bastante antigo e tem algumas alusões, como em 1830 e 1840 que, aparentemente, já era aludido no sertão nordestino e teria sido empregado pela primeira vez em 1872 por Domingos Vieira, significando: "reunião de objetos menores e confusos, utensílios das famílias humildes, mobília de pobre e escravo". No entanto, apresentam-se outras definições para denominar o cangaço nos dias atuais. Uma delas foi registrada por Henrique de Beaurepaire no Dicionário de vocábulos brasileiros, em 1889, que indica "conjunto de armas que costumam conduzir os valentões".

Outra explicação para o termo refere-se ao objeto canga, que deu nome tanto a um equipamento de tortura, como ao equipamento cangalha usado no lombo de bois e de outros animais de tração. No primeiro caso, a canga se assemelhava ao tronco que era usado para castigar os escravos e denotava a ideia de subjugação, de opressão. Utilizar o termo cangaço em referência ao tronco significava liberdade, independência, dignidade, representada no dito popular "nesse pescoço não se bota canga", expressando a ideia de que aqueles homens não tinham mais um dono. No segundo caso, tratava-se de um utensílio que foi bastante utilizado como meio de transporte e de carga.

Pericás (2010) considera que as duas alusões mais comuns para designar o termo cangaço estão relacionadas de forma específica à canga. A primeira alusão se referia a subordinação ou independência dos cangaceiros aos coronéis, na representação de um instrumento de prisão ou tortura, tal qual, o objeto cangalha é colocada no lombo de um animal. A segunda alusão está relacionada à ligação com a canga de boi, instrumento de madeira que traz os animais lado a lado, remetendo o conceito de união.

A ideia de relacionar o termo cangaço ao objeto canga tem significados expressivos, denotando a relação ou repulsa ao sistema vigente entre os períodos de surgimento e perpetuação de bandos armados. Essa atuação inicialmente não recebeu o nome de cangaço. Pericás (2010) classifica a aparição dos primeiros bandos armados pelo sertão nordestino ainda no século XVII, com os soldados holandeses e bandeirantes paulistas em suas missões expedicionárias que o autor denomina de "bandoleiros". Tais exemplos teriam sido a "base de constituição" para que, posteriormente, recebesse a denominação de cangaço.

Posteriormente, no século XVIII, houve a atuação do pernambucano José Gomes, que ficou conhecido como "Cabeleira" e, na primeira metade do século XIX, a atuação de Lucas Evangelista, o "Lucas da Feira", atuando entre o Agreste e o Recôncavo baiano. De acordo com Pericás (2010, p. 17), estes dois casos "[...] podem ser vistos como 'precursores' do que se definiu mais tarde como cangaço". Mesmo havendo essas constatações na historiografia do cangaço, à época, até a primeira metade do século XIX, não havia organicidade de atuação, nem uma imagem definida do cangaceiro que caracterizasse o movimento com representatividade no sertão nordestino.

A atuação de bandos armados pelo sertão nordestino até meados do século XIX acontecia com mais incidência em períodos de seca, mas, sabe-se que os motivos que levaram esses bandos a perambularem pelo sertão nordestino não encontram seu cerne simplesmente na seca. Há muitas questões relacionadas à miséria disseminada pelo Nordeste, como apontado por Castro (1992) ao discorrer que a elite coronelística se beneficiava da miséria que atingia as classes baixas para perpetuar suas riquezas. Pensa-se que, em virtude 
dessa constatação, muitos autores cometem, de certa forma, um equívoco ao determinar as condições climáticas, neste caso, a seca no Nordeste, como fator preponderante para o surgimento do cangaço.

A organização social no Nordeste fazia com que as famílias ficassem reféns de alguma ordem, quer seja dos coronéis, quer seja da igreja. O mandonismo, notadamente no Nordeste, fez com que, ao longo dos séculos, surgissem movimentos que sempre estavam ligados a um líder. As lideranças comandavam o povo nordestino que, no geral, o aprisionava sob suas ordens ou preceitos. Era comum que as famílias estivessem reunidas sob a "proteção" de coronéis ou líderes religiosos como forma de assegurar-lhes a sobrevivência.

No entanto, foi na passagem do século XIX para o XX que houve uma intensificação da formação de bandos armados - à época, já se atribuía a esses grupos o termo cangaço. Pericás (2010) caracterizou o cangaço como endêmico e epidêmico; para o autor, antes de 1890, o cangaço se configurava como endêmico, pois a aparição de bandos armados se dava de forma esporádica e muitos deles estavam subjugados às ordens de um determinado coronel. Já nas primeiras décadas do século XX, o cangaço chegou ao auge de sua existência como cangaço epidêmico, porque foi entre as décadas de 1890 a 1940 que mais surgiram bandos independentes pelo sertão nordestino representados por lideranças como Antônio Silvino, Sinhô Pereira e Lampião, considerados como alguns dos maiores nomes no cangaço.

As condições básicas para o surgimento do movimento do cangaço foram caracterizadas por Mello (2011, p. 140, grifo nosso), em três: "Cangaço [como] meio de vida, cangaço [como meio] de vingança e o cangaço como refúgio". O cangaço como meio de vida tinha um sentido profissional, se configurava como uma alternativa de trabalho, uma atividade que assegurava a sobrevivência. $\mathrm{O}$ cangaço de vingança seria um meio que os homens encontravam para vingar-se de alguma ofensa física ou moral. O cangaço como refúgio era a garantia de proteção, um esconderijo para homens perseguidos.

Essas distintas condições também foram caracterizadas a partir da atuação de diferentes cangaceiros. No século XIX, Jesuino Brilhante ficou conhecido como um cangaceiro nobre, associado em algumas literaturas à figura de Robin Hood; Zé Baiano, por sua crueldade ao ferrar as mulheres com as iniciais do seu nome, como se fazia com o gado; e Lampião é mencionado em várias literaturas de forma bastante contraditória, ora como um cangaceiro cruel, impiedoso, ora como bondoso que ajudava os pobres.

Pode-se dizer que os bandos de cangaceiros aderiam ao movimento do cangaço por causa de disputas, em busca de refúgio, por desonra familiar e vingança. Esses motivos estavam ligados a disputas que envolviam desde brigas por extensões de terras, fazendas, furto de animais, discussão por motivos fúteis, desonra familiar por assédio moral ou sexual, entre outros, não importando a classe social a qual pertencia o futuro cangaceiro. Pericás $(2010$, p. 37) aponta que: "[...] as questões de honra muitas vezes sobrepassavam as questões fundiárias em algumas instâncias". A honra vinha em primeiro lugar ao classificar um homem sertanejo.

Os estados nordestinos mais citados como tradicionais celeiros de cangaceiros são Ceará, Pernambuco e Paraíba. Dentre os condicionantes para a propagação do movimento do cangaço em áreas sertanejas e, principalmente, nos estados mencionados, foi a condição do relevo irregular que propiciava esconderijos naturais como fator fundamental para que o movimento se expandisse e se convertesse de endêmico para epidêmico (MELLO, 1985). A condição do relevo irregular por lajedos e rochas auxiliava os cangaceiros a despistarem as forças policiais, caminhando sobre rochas, lajedos e chão duro para não deixarem rastros ou empregando outras técnicas para confundir os perseguidores.

Nesse aspecto, o meio físico local é tomado pelas habilidades espaciais e pelos conhecimentos espaciais, que transformaram pela experiência essas localidades em lugar para os cangaceiros: a intervenção da cultura dos sujeitos sobre os objetos naturais. Nessa relação entre a cultura cangaceira e a natureza, podemos dialogar com Cosgrove (2004, p. 103) que, ao investigar a relação entre a cultura e a natureza, indica a força da intervenção do sujeito sobre os objetos dispostos na natureza: "[...] O objeto natural torna-se um objeto cultural, foi-lhe atribuído um significado. O significado cultural é introduzido no objeto e também pode ligálo a outros objetos aparentemente não relacionados a ele na natureza".

O movimento do cangaço teve maior atuação nos estados de Alagoas, Sergipe, Pernambuco, Paraíba, Ceará, Bahia e Rio Grande do Norte. Estes estados que tiveram a incidência do movimento do cangaço são dotados de particularidades, com vegetação própria, clima, tipo de solo, relevo, etc. As características físicas fazem com que sejam atribuídos nomes a localidades e coisas; pela sua caracterização são passíveis de serem identificadas por meio de narrativas e descrição do lugar através de sua paisagem. A partir da vivência no lugar, do conhecimento com o meio, o sujeito desenvolve o sentido de orientação e localização. Quanto ao sentido de lugar, Oliveira (2012, p. 15) afirma que: "As dimensões significativas do lugar, que na realidade é o sentido que se atribuiu a este ou aquele (o meu lugar, o seu ou o nosso lugar), são pensadas em termos geográficos a partir da experiência, do habitar, do falar e dos ritmos e transformações". 
Para atrair as forças policiais, os cangaceiros escolhiam os melhores lugares onde pudessem fazer trincheiras com o que a natureza lhes oferecia. Arrastavam-se pelo chão, escondiam-se por trás de rochas, troncos de árvores, tudo que estava à disposição no meio ambiente servia-lhe de trincheira. As emboscadas para as forças policiais eram estratégicas, examinava-se o terreno, as condições de relevo e a vegetação para que pudessem assegurar a sobrevivência do bando em combates. O conhecimento do meio ambiente era a garantia da vida cangaceira, que servia tanto para proteção, defesa e contra-ataques, quanto para suprir as necessidades básicas de sobrevivência.

Os cangaceiros possuíam um sólido conhecimento com as localidades e com o meio ambiente que os circundavam: com a caça para se alimentar, com as plantas medicinais para cada doença ou ferimento específico, o senso de orientação na mata, tudo isto se tratava do conhecimento do meio, aquele conhecimento geográfico simples que não precisa ser alfabetizado para desenvolvê-lo, que se pratica sem pensar - a esta relação Tuan (2013) trata como as relações íntimas dos sujeitos com o meio ambiente.

O conhecimento do meio era de fundamental importância para a sobrevivência dos cangaceiros que caminhavam por longos itinerários percorrendo veredas, buscando se proteger na caatinga das forças policiais e na procura por esconderijos para seus pousos. Atrelado a esse conhecimento popular, o meio ambiente propiciava as andanças cangaceiras facilitando o deslocamento dos bandos. Paiva (2004) discorre que a vida cangaceira na caatinga nordestina se caracterizava por uma vida andeja e perigosa que impunha algumas condições para as ações bandoleiras, sendo a mais importante: $\mathrm{o}$ alto conhecimento da caatinga para localizar-se, se proteger; a capacidade de encontrar água e alimentos; e a utilização da medicina sertaneja, por meio do conhecimento popular, para tratar de doenças, ferimentos, infecções, etc.

A vivência como vaqueiros, agricultores e a atuação das benzedeiras no sertão nordestino propiciava o conhecimento do meio, aquele conhecimento popular de se orientar durante o dia pelo sol, à noite pelas estrelas, de utilizar as plantas medicinais corretas para doenças, a oração com a benzedura que cura mal olhado, quebrante, íngua, fecha o corpo, tudo em um local certo proporcionado pelo meio ambiente. Assim, essa vivência com o meio transforma as relações entre os sujeitos e a natureza, ao passo que, enquanto o homem se adapta e transforma o meio ambiente, ele é igualmente transformado pela contextualização cultural que o faz apropriando-se dos objetos naturais.

O saber popular dos sertanejos reflete a construção humana e social dos sujeitos. Os saberes praticados que são repassados por gerações, transmitindo suas experiências pelas narrativas as quais os sujeitos se reconhecem e foram produzindo sua identidade na cultura em que foram constituídos. Um saber legitimado pelos sujeitos que fazem desses conhecimentos outras práticas do viver, inventados e reinventados cotidianamente como formas de resistência de suas culturas (TUAN, 2012).

A capacidade de orientação dos cangaceiros estava relacionada com seus conhecimentos popular, ou seja, a condição que tinham de explorar o ambiente onde sobreviviam, relacionando-se também com a "ecologia dos lugares", percorrendo caminhos e veredas na caatinga. Essas andanças dos cangaceiros exigiam um alto conhecimento do terreno, da caatinga e do sertão para se deslocarem, para a utilização das benzeduras, com os remédios tirados da natureza para tratar dos corpos mutilados marcados por peixeira e penetrados por espinhos e balas.

Esse conhecimento topofílico foi de fundamental importância para a sobrevivência e os vários anos que se seguiram da atuação dos bandos de cangaceiros, no sertão nordestino. O conhecimento cultural no qual foram constituídos permitiu-lhes traçar estratégias e formas de sobrevivência no meio ambiente em que atuaram. Assim desenvolveu-se uma geografia do cangaço da sociedade sertaneja nordestina a qual pertenceram os grupos de cangaceiros, tomando esses conhecimentos pelos lugares que se constituíram para os bandos e as toponímias produzidas no contexto sociocultural do grupo revelando uma verdadeira relação socioespacial entre os cangaceiros e o meio.

\section{O lugar do bandido/cangaceiro}

Os sujeitos enquadrados no banditismo passam a viver como nômades, e esta é uma semelhança com o movimento do cangaço. Os cangaceiros, quando tomavam a decisão de fazerem vida no movimento, passavam a habitar as matas, fazendo, dessa forma, daquele espaço o seu lugar, estabelecendo itinerários, de modo a suprirem suas necessidades básicas de sobrevivência.

Assim, o lugar do bandido cangaceiro situava-se à margem da sociedade urbana, habitando as mais variadas localidades, com suas diferentes estruturas geomorfológicas presentes em todo o sertão nordestino, por onde houve atuação do cangaço. Um espaço onde as forças policiais nem sempre estavam aptas a percorrer e que os cangaceiros se sentiam seguros e protegidos por terem o conhecimento do terreno e da 
paisagem, uma característica do conhecimento presente nas geografias vernaculares, conforme Claval (2014).

Além das questões sociais agravadas pelos longos períodos de seca no sertão nordestino e o quadro de miséria, as elites coronelísticas aproveitavam-se das calamidades para manterem seus status quo, (CASTRO, 1992), no meio cultural onde aquela sociedade fora alicerçada. O patriarcalismo e o machismo eram forças estruturantes da sociedade sertaneja do Nordeste. A concepção de que o homem de bem não podia ser desmoralizado pelo fato de que o bem mais precioso para o sertanejo nordestino era o seu nome, sua honra, foi motivo de muitas desavenças e mortes.

Ao ingressar no cangaço, tornando-se bandido/cangaceiro, este sujeito garantia sua honra, reafirmava sua valentia, o que lhe permitia adentrar os locais que tivesse interesse, mesmo que não fosse bem-vindo. A força do punho e das armas eram suas garantias e a permissão para adentrar. O lugar do bandido/cangaceiro era fora do alcance da sociedade urbana, à margem de um código de conduta cívico, buscando cumprir o objetivo para reintegrar sua honra inserindo-os na imagem de "cabra macho", dentro de outro universo social, o de pertencer à classe dos homens de bem.

Dessa forma, o lugar do bandido/cangaceiro, era sob o código moral sertanejo, da não desmoralização, da não humilhação, justificando assim, sua atuação cangaceira em busca de vingança por atos de desonra. Essa ideia de não aceitar uma desonra na família, e por isso mesmo, buscar no cangaço um meio de vingar-se, ainda hoje é legitimada pelos sertanejos nordestinos, do ponto de vista, do reconhecimento da atuação dos cangaceiros como sujeitos valentes que lutavam para "limpar" sua honra, justificando nesse sentido, a formação de bandos de cangaceiros, a partir do fator da vingança.

Ora, e qual o lugar do bandido após sua morte? Essa indagação permeia uma série de questões referentes aos seus restos mortais, assim como seu espírito. Assim, vamos nos ater a dois episódios de morte no movimento do cangaço: a morte do cangaceiro Jararaca (pertencente ao bando de Lampião), em decorrência ao ataque em Mossoró, Rio Grande do Norte (1927), e ao fuzilamento dos cinco cangaceiros do bando dos Marcelinos, no Cariri cearense (1928).

A morte do cangaceiro Jararaca é relatada de algumas maneiras (enterrado vivo, morto a tiros, etc.). No entanto, o que se tem em comum nas versões é que a polícia foi responsável pela morte do cangaceiro que se encontrava gravemente ferido, em Mossoró, e seria transferido para a capital, Natal. Na possível transferência, Jararaca foi morto e enterrado, sem sair do município de Mossoró (FALCÃO, 2011).

As narrativas a respeito das mortes dos cangaceiros do bando dos Marcelinos, no Cariri cearense, retratam uma ação policial de forma arbitrária, a mando do estado, pelo desembargador Moreira da Rocha, no qual foi proferida a sentença da execução pelo fuzilamento dos cinco cangaceiros, sem julgamento. Os cangaceiros foram obrigados a cavarem suas próprias covas e foram fuzilados um a um, na comunidade Alto do Leitão, município de Barbalha (COSTA, 2020).

Nas duas situações de morte relatada, os sujeitos sertanejos nordestinos que se reconhecem nessas narrativas, atribuem significado de piedade popular aos cangaceiros, pelas mortes trágicas que tiveram. Essa piedade popular é conotada, pelos sujeitos que seguem os ritos do catolicismo popular, no sentido da comoção pelo sofrimento em suas horas finais, sem direito a uma sentença de julgamento.

Para os sujeitos pertencentes ao grupo religioso do catolicismo popular que creem em céu, inferno e santo(a)s, eles acreditam que todas as pessoas, após sua morte, têm o direito de serem enterradas dignamente e que os pecados cometidos fica a encargo do(a) pecador(a) prestar contas a Deus. Os relatos de muitos sujeitos no Cariri cearense, em relação ao fuzilamento dos cangaceiros do bando dos Marcelinos, por exemplo, evidenciam que mesmo tendo cometido muitos crimes, os cangaceiros não podiam ter sido obrigados a cavarem suas próprias covas e em seguida serem fuzilados. Deveriam ter sido julgados e condenados a cumprirem pena prisional. Em caso de morte, não mereceriam ser enterrados como indigentes, mas, inclusive, serem celebradas missas e orações para libertação de suas almas.

Acredita-se que os cangaceiros eram católicos ou seguiam os ritos de um catolicismo popular, possuindo devoção a determinados santos, estavam sempre fazendo orações e carregavam consigo símbolos da religiosidade de determinada crença. Muitos cangaceiros, por exemplo, costumavam rezar com seu bando pedindo proteção para fechar o corpo, sendo comum os cangaceiros ornamentarem-se com um rosário, um terço, um escapulário no pescoço, representando um sentido de devoção.

A sepultura do cangaceiro Jararaca, atualmente é uma das mais visitadas em Mossoró, por sujeitos nordestinos que manifestam sua devoção popular, sobretudo, pelos fatos que cercam sua morte, reinterpretado, pelo modelo do martírio cristão (FREITAS, 2007). Essa forma de reconhecimento a um determinado grupo social, os sertanejos habitantes da caatinga, no qual se desenvolvem traços culturais 
próximos entre si, simboliza o contexto cultural-religioso do catolicismo popular em uma expressão cultural que marca esses sujeitos como grupo social, interligados por um contexto intersubjetivo do lugar, a saber, o sertão nordestino.

As mortes trágicas dos cangaceiros tornaram-se acontecimento emblemático da violência social e, contraditoriamente, sugeria uma mitigação para os crimes cometidos pelos cangaceiros. $\mathrm{O}$ ato da violência social cometida contra estes gerou uma forma de remissão para os crimes antes cometidos. A morte trágica apresenta-se como a "absolvição" desses sujeitos por parte da sociedade.

O pertencimento a este universo de costumes e crenças leva os sujeitos a acreditar que esses bandidos/cangaceiros deveriam ser punidos pelos crimes cometidos. No entanto, tinham o direito de receber o perdão em vida ou na morte, assim como Deus concede o perdão aos pecadores que demonstrem arrependimento. No caso dos cangaceiros terem tido mortes trágicas, a interseção popular, por meio da devoção e oração, orienta aos espíritos dos cangaceiros conseguirem a remissão dos pecados.

Dessa forma, a concepção da morte trágica, sem direito a julgamento terreno, pode conferir ao bandido/cangaceiro um status de mártir, garantindo-lhes outra concepção, outra visão junto aos sujeitos que possuem a crença nesse aspecto simbólico do catolicismo popular. Conforme a concepção de Freitas (2007), o bandido pode passar a ser visto como mártir após o ato da morte trágica, no qual as pessoas passam a rezar pela alma dele como forma de piedade popular, encomendando sua alma a Deus.

O local da morte passa a ter um reconhecimento, uma ressignificação daquele espaço, por parte dos sujeitos pertencentes aos ritos do catolicismo popular. $\mathrm{O}$ ato das mortes dos cangaceiros, que configurou $\mathrm{o}$ fim trágico daqueles homens, mudou as formas de percepção de parte da sociedade no contexto sociocultural dos sujeitos que conhecem a história do movimento do cangaço. Se antes eram tidos como bandidos, o que se nota no presente é uma visão que conota piedade popular.

Não cabe julgar se a visão correta é a de mártires ou de bandidos, mas podemos ponderar que as várias localidades que marcaram a vida e a morte de diversos cangaceiros, hoje têm um sentido de lugar para uma coletividade, para um grupo de sujeitos que, ao reconhecerem a importância cultural e histórica dos cangaceiros para o contexto local, reafirmam a própria cultura do lugar e dos sujeitos pertencentes a este grupo social.

Nessa seara, o grupo social que se reconhece na história de atuação dos cangaceiros, passaram a interceder, por meio da oração, pelo espírito do cangaceiro que teve morte trágica, atribuindo nesse sentido, um "bom lugar" ao bandido/cangaceiro que morreu tragicamente, sem o direito do julgamento terreno. Os cangaceiros (seus espíritos) passaram a ter a piedade popular, daqueles sujeitos que se reconhecem no contexto histórico-cultural local.

\section{Considerações finais}

Culturalmente as questões de honra e valentia no sertão nordestino, foram basilares para a efervescência do movimento do cangaço, permeando as vivências do sertanejo do Nordeste, como homens destemidos, corajosos que lutava, matavam e morriam em nome da honra. Essas percepções, no entanto, ainda hoje estão presentes no imaginário, no cotidiano do grupo de sujeitos que vivenciaram ou foram ouvintes das histórias de cangaceiros que desafiavam a própria vida para manter o status de "cabra macho"

Dessa forma, as relações que permeiam o universo dos movimentos sociais, culturais, etc., não devem ser homogeneizadas por uma única teoria, sobretudo, quando esta teoria não foi elaborada para um grupo específico. Não convêm aplicar os mesmos conceitos para caracterizar distintos movimentos, sujeitos ou lugares. As especificidades dos lugares, dos sujeitos, devem ser levadas em consideração para se desenvolver uma pesquisa a respeito da formação e atuação de determinados movimentos sociais, culturais, etc.

Nessa seara, as ligações que conotam a explicação do termo, cangaço, nos apresentam apontamentos possíveis para caracterizar o movimento do cangaço, como movimento de banditismo sertanejo, ao invés de padronizar, na concepção de banditismo social, elaborada por Eric Hobsbawm. As particularidades dos lugares e dos sujeitos, constituídos culturalmente ao longo das vivências, não se apresenta da mesma condição, por exemplo, no Brasil, na Itália, na África do Sul, dentre outros.

Nesse sentido, acredita-se que o movimento do cangaço, poderá ser melhor compreendido, no contexto do banditismo sertanejo, levando em consideração a relação cultural de sertanejo nordestino, alicerçado em uma cultura de valentia, de honra, de "cabra macho", vinculado ao código moral sertanejo de que uma desmoralização não ficava impunemente. 
Embora o sertão nordestino, tenha sido uma terra onde sempre prevaleceu à força das elites, não se reduziram as formas de resistência, não seria, então, surpreendente que surgissem movimentos de luta e combate à tirania e às políticas impostas por essa elite. A luta pela honra sertaneja está inserida no movimento do cangaço, assim como em diferentes movimentos de levante contra as injustiças ditadas por uma sociedade controladora do direito de viver.

Os bandos de cangaceiros produziram com suas atuações, uma geografia do cangaço que retrata a cultura de um grupo social de sertanejos nordestinos, influenciado culturalmente pela noção de honra, de valentia e de "cabra macho" que desenvolveu ao longo da história toponímias, valores, sentimentos e a construção do sentido de lugar na caatinga nordestina dada ao vínculo de pertencimento e afetividade dos sertanejos nordestinos com esse lugar.

A cultura, a paisagem, as vivências no lugar da caatinga conformaram a imagem do cangaceiro, a qual instituiu, por meio da atuação dos bandos, uma geografia do cangaço, própria do sertão da caatinga, com características marcantes, dadas as particularidades culturais desse ambiente, onde essas características específicas do cangaço, pode ser apresentado por meio da constituição do conceito de banditismo sertanejo, no intuito de caracterizar o movimento do cangaço, como um movimento eminentemente nordestino, dotado do discurso de honra, por meio da figura do "cabra macho".

\section{Agradecimentos}

Grata à Coordenação de Aperfeiçoamento de Pessoal de Nível Superior (CAPES) pelo apoio financeiro no decorrer da pesquisa de mestrado.

\section{Referências}

ALMEIDA, M. G. Em busca do poético do sertão: um estudo de representatividade. In: ALMEIDA, M. G.; RATTS, A. J. P. (Orgs). Geografia: leituras culturais. Goiânia: alternativa, 2003. p. 71-88.

BARROS, L. O. C. A derradeira gesta: Lampião e Nazarenos guerreando no Sertão. Rio de Janeiro: Mauad, 2007.

BARROS, L. O. C. Cangaço - violência no Sertão do Nordeste. Ponta de Lança: revista eletrônica de história, memória \& cultura. v. 12, 2018. 62-77. Disponível em: $\langle$ https://seer.ufs.br/idex.php/pontadelanca/article/view/9317/pdf $>$.

BARROSO, G. Almas de lama e de aço: Lampião e outros cangaceiros. Rio - São Paulo - Fortaleza: ABC, 2012.

BERDOULAY, V.; ENTRIKIN, N. Lugar e sujeito: perspectivas teóricas. In: MARANDOLA JR., Eduardo; HOLZER, Werter; OLIVEIRA, Lívia de. (Orgs). Qual o espaço do lugar? São Paulo: perspectiva, 2012. p. 93-116.

CASTRO, I. E. O mito da necessidade: discurso e prática do regionalismo nordestino. São Paulo: Bertran Brasil, 1992.

CLAVA, P. Epistemologia da Geografia. 2. ed. Florianópolis: Editora da UFSC, 2014.

COSGROVE, D. A geografia está em toda parte: cultura e simbolismo nas paisagens humanas. In: CORRÊA, R. L.; ROSENDAHL, Z. (orgs). Paisagem, tempo e cultura. Rio de Janeiro: EdUERJ, 2004. p. 92-123.

COSTA, A. P. R. Lugar e memória: a vida cangaceira do bando dos Marcelinos em Barbalha - CE. Revista da Casa da Geografia de Sobral (RCGS). v. 22, 52-67, 2020. DOI: $\underline{10.35701 / \mathrm{rcgs} . v 22 n 1.413}$

FALCÃO, M. L. Uma morte muito aperreada: memória e esquecimento nas narrativas sobre um cangaceiro de Lampião em Mossoró. 2011. 185. f. Dissertação (mestrado em História Social). Centro de Humanidades, Universidade Federal do Ceará, Fortaleza, 2011. 
FREITAS, E. T. As vidas e as mortes de Jararaca: narrações de uma devoção popular no Nordeste brasileiro. Revista de Estudos da Religião. ano. 7, 1-30, 2007. Disponível em: <http://www.pucsp.br/rever/rv4 2007/index.html>.

HOBSBAWM, E. Bandidos. 4. ed. São Paulo: Paz e terra, 2015.

HOBSBAWM, E. Rebeldes primitivos: estudos de formas arcaicas de movimentos sociais nos séculos XIX e XX. Rio de Janeiro: Zahar editores, 1978.

LINS, D. Cartografia do bandido social: o caso e a necessidade. Revista de Ciências Sociais. V 27, N 1/2, p 169-179, 1998. Disponível em: 〈http://www.periodicos.ufc.br/revcienso/article/view/42585/99614>

MELLO, F. P. Guerreiros do sol: o banditismo no Nordeste do Brasil. Recife: Massangana, 1985.

MELLO, F. P. Guerreiros do sol: violência e banditismo no Nordeste do Brasil. São Paulo: A Girafa, 2011.

OLIVEIRA, L. O sentido de lugar. In: MARANDOLA JR., E.; HOLZER, W.; OLIVEIRA, L. (Orgs). Qual o espaço do Lugar? Geografia, epistemologia, fenomenologia. São Paulo: Perspectiva, 2012. p. 03-16.

PAIVA, M. P. Ecologia do cangaço. Rio de Janeiro: Interciência, 2004.

PERICÁS, L. B. Os cangaceiros: ensaio de interpretação histórica. São Paulo: Boitempo, 2010.

TUAN. Y. F. Topofilia: um estudo da percepção, atitudes e valores do meio ambiente. Londrina: Eduel, 2012.

TUAN. Y. F. Espaço e lugar: a perspectiva da experiência. Londrina: Eduel, 2013.

(1) (5) (2)

Este artigo é distribuído nos termos e condições do Creative Commons Attributions/AtribuiçãoNãoComercial-CompartilhaIgual (CC BY-NC-SA). 